\title{
PEMAHAMAN HEDONISME KONTEMPORER BERDASARKAN STUDI TEOLOGIS DALAM ROMA 6:2 DAN GALATIA 5:19 SERTA IMPLIKASINYA BAGI ORANG KRISTEN MASA KINI
}

\author{
Widia Wahyuni ${ }^{1}$, Yosep Iswanto Padabang ${ }^{2}$ \\ 1Sekolah Tinggi Teologi Injili Arastamar (SETIA) Jakarta \\ 2STT Arastamar Wamena \\ 11widiawahyuni054@gmail.com \\ 2yosepiswanto3@gmail.com
}

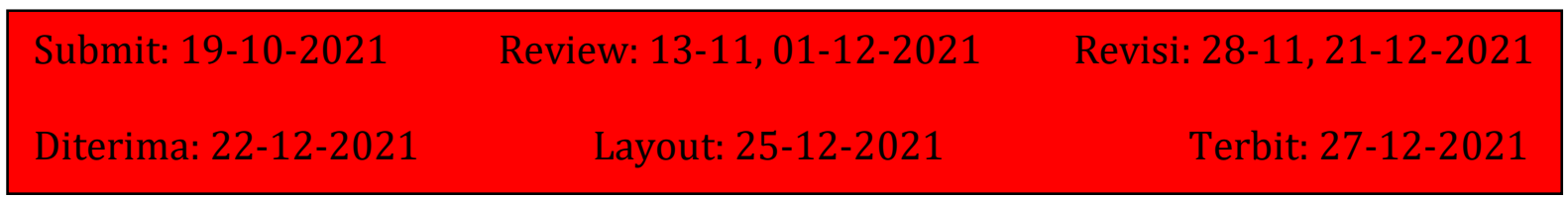

\begin{abstract}
Searching for happiness in life is something that is always coveted by everyone, but in seeking and finding it someone needs to be guided and encouraged by the right motivation, so that the happiness obtained can be enjoyed properly, not to satisfy the desires of the flesh which ultimately makes the human being. perish with this world. As taught in the Bible that humans should always live to seek and please God, but in reality what is seen today is, there are so many people who live looking for happiness to satisfy their desires not God's desires. Then what about the life of Christians today? The author uses descriptive qualitative methods, while related to theological studies in relation to the hedonistic lifestyle, the authors relate descriptive qualitative research in the context of phenomenology with qualitative methods that are library research. Which is to analyze the content of meaning contained in a narrative or text, in relation to the Scriptures, the author uses narrative analysis. And in the end it can be concluded that believers should always live according to God's will, which is to do things that show love for God. and abstain from Deeds that originate from the desires of the flesh. and always pursue eternal happiness not temporary happiness taught in hedonism.
\end{abstract}

Keywords: Lifestyle, Hedonism, Believers

\begin{abstract}
Abstrak
Mencari kebahagiaan dalam hidup ini adalah sesuatu yang selalu didambakan oleh semua orang namun dalam mencari dan menemukannya seseorang perlu dibimbing dan didorong oleh suatu motivasi yang benar, sehingga kebahagiaan yang diperoleh dapat dinikmati dengan baik, bukan untuk memuaskan keinginan daging semata yang pada akhirnya membuat manusia tersebut binasa dengan dunia ini. Sebagaimana yang diajarkan dalam Alkitab bahwa manusia sebaiknya selalu hidup mencari dan menyenangkan hati Tuhan, namun pada kenyataannya yang terlihat saat ini adalah, ada begitu banyak orang yang hidup mencari kebahagiaan untuk memuaskan keinginannya bukan keinginan Tuhan. Lalu bagaimana dengan kehidupan orang Kristen saat ini? Penulis menggunakan metode kualitatif deskriptif, sedangkan terkait dengan kajian teologi dalam kaitannya dengan gaya hidup hedonisme, penulis mengaitkan penelitian yang bersifat kualitatif deskriptif dalam konteks fenomenologi dengan metode kualitatif yang bersifat library research. Yang mana untuk menganalisis kandungan makna yang terdapat dalam sebuah narasi atau teks, dalam kaitannya dengan Kitab Suci, penulis menggunakan analisis naratif. Pada akhirnya dapat disimpulkan bahwa orang percaya sebaiknya selalu hidup menurut keinginan Tuhan, yaitu melakukan hal-hal yang memperlihatkan kasih kepada Allah. dan menjauhkan diri dari Perbuatan yang bersumber dari keinginan daging. serta selalu mengejar kebahagiaan yang abadi bukan kebahagiaan sementara yang diajarkan dalam paham hedonisme.
\end{abstract}


Kata Kunci: Gaya Hidup, Hedonisme, Orang Percaya

\section{Pendahuluan}

Hedonisme merupakan salah satu gaya hidup yang memiliki gaya Tarik yang cukup kuat teruatama pada kalangan remaja dan anak muda saat ini, sebagaimana yang terlihat dalam perilaku mereka yaitu cenderung memilih hidup yang mewah, enak, dan serba kecukupan tanpa harus bekerja kerasa mengeluarkan keringat. ${ }^{1}$ berkaitan dengan perilaku hal ini Filowers juga menekankan bahwa hedonisme dapat diartikan sebagai pola perilaku yang dapat diketahui dari aktivitas, minat maupun pendapat yang selalu menekankan pada kesenangan dan kenikmatan hidup semata. ${ }^{2}$

Tentu bahwa salah satu hal yang juga ikut memengaruhi cara pandang ini adalah gaya hidup yang dimiliki oleh manusia tersebut, dalam menjalani keseluruhan eksistensi hidupnya. Sebagaimana yang dikemukakan oleh Garlans ${ }^{3}$ dalam tulisannya mengatakan bahwa gaya hidup adalah suatu bentuk dari saling interaksi antara manusia sehinga memicu suatu pola dalam kehidupan. Masih terkait dengan pengertian yang sama dari Frasa Gaya Hidup Kasali juga mengemukakan bahwa gaya hidup pada prinsipnya adalah bagaimana seseorang menghabiskan waktu dan uangnya. ${ }^{4}$ Tentu bahwa dari kedua pernyataan ini penulis mengerti gaya hidup adalah sesuatu yang selalu melekat pada diri setiap orang, dan juga ikut memengaruhi keberadaan dari pribadi manusia itu sendiri, yang juga berkaitan erat dengan perilaku seseorang dalam menghabiskan waktu dan uangnya.

Dalam melihat gaya hidup ini, suatu perubahan gaya hidup pada manusia tentu tidak hanya dipengaruhi oleh faktor internal dalam diri manusia namun dipengaruhi oleh faktor eksternal yang ada di laur diri manusia. Hal ini sebagaimana yang dikemukakan oleh Suryanti ${ }^{5}$ bahwa perkembangan Ilmu pengetahuan dan teknologi (IPTEK) dan perubahan gaya hidup di kalangan kaum muda berpengaruh terhadap cara pandang dan sikap kaum muda terhadap agama. Melihat pernyataan suryani ini, ada suatu penekanan yang dikemukakan oleh suryani yang penulis mengerti bahwa suatu perubahan IPTEK memiliki dampak dalam menghasilkan cara padang manusia dalam melihat segala sesuatu termasuk cara pandangnya terhadap Agama.

Berbicara tentang gaya hidup akan menjadi menarik jika kita hubungkan dengan perilaku hedonisme, yang saat ini sedang terjadi pada semua kalangan masyarakat di era modern. Berkaitan dengan Hedonisme, Bertens mengatakan bahwa Hedonisme pertama kali dikemukakan oleh seorang filsuf dari Yunani yang bernama Aristippos tahun 433-335 SM, yang mengatakan bahwa hal terbaik bagi manusia adalah kesenangan. ${ }^{6}$ Aristippos juga menekankan bahwa, Kesenangan di sini harus dimengerti sebagai kesenangan yang aktual. Sedangkan gaya hidup hedonisme merupakan pola

1 Ranti Tri Anggriani \& Fauzan Heru Santhoso, "Hubungan Antara Gaya Hidup Hedonis Dengan Perilaku Konsumtif Pada Remaja," GADJAH MADA JOURNAL OF PSYCHOLOGY 3, no. Gaya Hidup Hedonis (2017): 133.

2 Haryono Makoagow dan Lamsike Pateda, "Pengaruh Gaya HIdup Hedonisme Dan Dampaknya Terhadap Hasil Belajar PAI DI SMAN 1 Pinolosian Kab. Bolaang Monggondow Selatan,” Jurnal Pendidikan Agama Islam dan Budi Pekerti 1, no. 2 (2019): 15.

3 Peter Garlans, Jangan Menjadi Budak Uang (Jakarta: Penerbit Guepedia, 2009), 69.

4 R. Kasali, Membidik Pasar Indonesia: Segmentasi, Targetting, Positioning (Jakarta: Gramedia Pustaka Utama, 2008), 225.

5 Ch. Suryanti, "Agama Dan Iptek: Refleksi Dan Tantangannya Dalam Mengembangakan Moralitas Anak Muda," Orientasi Baru 19, no. Agama dan IPTEK (2010): 155.

${ }^{6}$ Karl Bertens, ETIKA (Jakarta: Gramedia Pustaka Utama, 2004), 236. 
hidup atau interkasi seseorang dengan lingkungannya yang hanya berorientasi pada kesenangan atau kenikmatan dalam kegiatan, minat, dan pendapat. ${ }^{7}$

Berangkat dari perilaku gaya hidup hedonisme ini, pada zaman sekarang tidak sedikit orang yang hidup dalam aliran gaya hidup hedonisme, sebagaimana yang dapat kita ketahui bahwa, saat ini ada banyak orang yang hidupnya selalu mau mencari segala sesuatu yang untuk memuaskan keinginan hatinya, manusia ingin mau bersenangsenang menikmati segala sesuatu yang serba modern, sebagaimana yang ditemukan dalam penelitiannya Fatia Nur Azisa bahwa manusia sekarang ini lebih banyak menghabiskan waktunya untuk bersenang-senang serta menghabiskan waktunya untuk hal-hal yang menyenangkan keinginananya sendiri. ${ }^{8}$ Fakta lain juga menjelaskan bahwa perilaku gaya hidup hedonisme juga ikut memberikan pengaruh yang besar bagi anakanak remaja dan mahasiswa di perguruan tinggi, hal ini sepeti yang ditemukan dalam penelitian Novita Trimartati yang mengatakan bahwa ada sebagian mahasiswa yang mempergunakan uang jajan yang diberikan oleh orang tua kepada mereka untuk hal-hal yang menyenangkan keinginan mereka, di antaranya mereka pergunakan untuk jalan ke mall, membeli baju dan perhiasan yang sesuai dengan perkembangan zaman. ${ }^{9}$

Hal serupa ini, yaitu perilaku gaya hidup hedonisme tidak hanya terjadi pada orang-orang non-Kristen tetapi kita juga dapat menemukannya pada kehidupan orang Kristen saat ini di mana ada begitu banyak yang lebih mengutamakan hal-hal yang lebih memuaskan keinginan hatinya dari pada keinginan Tuhan, tidak hanya itu namun ada yang menggunakan hartanya untuk mencari kesenangan dari pada memberikannya untuk hal-hal yang berkaitan dengan misi dan pelayanan Tuhan di muka bumi ini. Sebagaimana yang dikemukakan oleh Prastiwi Bahwa pola hidup hedonis menumbuhkan sikap hidup yang berlebihan dalam menggunakan sarana kesenangan yang beraneka ragam. ${ }^{10}$

Melihat perilaku kehidupan hedonisme ini, jika dihubungkan dengan Pola hidup kekristenan yang didasarkan pada pengajaran dalam Alkitab, maka kita akan menemukan adanya perbedaan pandangan yang saling bertentangan antara pengajaran dalam Alkitab dengan gaya hidup hedonisme yang saat ini sedang terjadi pada manusia. Yang mana di dalam Alkitab selalu mengajarkan dan menekankan bahwa manusia perlu untuk hidup mencari dan melakukan segala sesuatu yang menyenangkan hati Tuhan. Bertolak dari pengajaran aliran Hedonisme yang kelihatannya sedikit bertentangan pengajaran kekristenan ini. Maka pertanyaan yang akan muncul adalah bagaimana membawa kehidupan Kristen saat ini untuk kembali dan tidak terjerumus dalam gaya hidup hedonisme ini? Dengan demikian maka tujuan dari penelitian ini adalah memberikan penjelasan dan kajian secara Teologis terkait dengan apa yang Alkitab tuliskan tentang Gaya Hidup hedonisme dan bagaimana implikasinya bagi orang percaya saat ini, sehingga orang percaya dapat terhindar dan tidak terjerumus dalam perilaku hedonisme

7 Endang Sri Indrawati Fatia Nur Azizah, "Kontrol Diri Dan Gaya Hidup Hedonis Pada Mahasiswa Fakultas Ekonomika Dan Bisnis Universitas Diponegoro,” Jurnal Empati Volume 4 (n.d.): 158.

8 Ibid., 157.

9 Novita Trimiarti, "Studi Kasus Tentang Gaya Hidup Hedonisme Mahasiswa Bimbingan Dan Konseling Universitas Ahmad Dahlan,” Psikopedagogian Vol.3 (2014): 25-27.

10 Tira Nur Fitria Prastiwi, Iin Emi, "Budaya Hedonisme Dan Konsumtif Dalam Belanja Online Ditinjau Dari Perpektif Ekonomi Syariah," Jurnal Ilmiah Ekonomi Islam 04, no. 2 (2020): 735. 


\section{Metode Penelitian}

Penelitian ini menggunakan pendekatan kualitatif deskriptif dengan metode kajian pustaka sebagaimana yang dikemukakan oleh Rawambaku, masalah yang telah dirumuskan harus segera diikuti dengan upaya mencari teori dan konsep, dan generalisasi yang dapat dijadikan landasan teoritis bagi penelitian yang akan dilakukan. ${ }^{11}$ Yang mana adapun masalah yang perlu dikaji saat ini yaitu banyak kehidupan orang percaya yang telah terjerumus dalam gaya hidup hedonisme. Terkait dengan kajian teologi dalam kaitannya dengan gaya hidup hedonisme, penulis menghubungkan dengan penelitian yang bersifat kualitatif deskriptif dengan metode Eksegesis untuk mengetahui kandungan makna dalam teks Alkitab Perjanjian Baru yang membicarakan tentang hedonisme dengan pendekatan yang bersifat bersifat library research. Creswell mengemukakan bahwa kualitatif research dilakukan untuk menganalisis kandungan makna yang terdapat dalam sebuah narasi atau teks, dalam kaitannya dengan Kitab Suci, ${ }^{12}$ penulis menggunakan analisis naratif. Gertz dan kawankawan mengemukakan bahwa untuk mengemukakan kandungan makna yang terdapat pada beberapa kata melalui penelusuran terhadap Alkitab,13 yang mana pada bagian ini penulis akan melihat dan menganalisa ayat Alkitab dalam Perjanjian Baru secara khusus dalam Roma 6:12 dan 7:20 yang berbicara tentang gaya hidup hedonisme. Dengan demikian maka dalam artikel ini penulis menggunakan metode kualitatif deskriptif, yang di dalamya juga penulis padukan dengan pendekatan library research dengan upaya analisa secara teoretis.

\section{Pembahasan}

\section{A. Gaya Hidup}

Satu hal serius yang selalu terjadi ketika kita membicarakan tentang keberadaan manusia pada suatu tempat adalah manusia tidak dapat dipisahkan dengan gaya hidup seperti apa yang sedang ia miliki dan jalani. Dengan demikian maka ketika kita mempelajari dan memahami gaya hidup, sebetulnya kita sendang memahami manusia itu sendiri. Melihat pernyataan ini Maka, saat kita berbicara tentang manusia sebenarnya kita juga sedang membicarakan gaya hidup yang manusia itu miliki. Namun yang menjadi pertanyaannya adalah lalu apa sebetulnya gaya hidup itu? Menurut Gerlans, gaya hidup merupakan suatu bentuk dari interaksi antara manusia sehingga memicu suatu pola dalam kehidupan. ${ }^{14}$ Di sini tentu Gerlans menekankan bahwa bicara gaya hidup berarti kita sedang membicarakan suatu bentuk interasi yang sedang terjadi antara satu manusia, dengan manusia yang lain. Tentu bahwa interaksi yang dimaksudkan di sini adalah suatu tindakan yang dilakuan oleh manusia itu sendiri yang kemudian akan menghadirkan suatu pola kehidupan bagi manusia, yang meliputi segala perilakunya setiap hari.

\footnotetext{
${ }^{11}$ Hendrik Rawambaku, Metode Penelitian Pendidikan (Jakarta: BPK Gunung Mulia, 2015), 103.

12 John W. Creswell, Research Design, Pendekatan Metode Kualitatif, Kuantitatif, Dan Campuran, 4th ed. (Yogyakarta: Pustaka Pelajar, 2016), 245.

13 Jan Christian Gertz, Angelika Berlejung, and Konrad Schmid Markus Witte, Purwa Pustaka, Eksplorasi Ke Dalam Kitab-Kitab Perjanjian Lama Dan Deuterokanonika, 1st ed. (Jakarta: BPK Gunung Mulia, n.d.), 47-48.

14 Antonius Purwanto Juolanda Tambingon, Femi C.M Tasik, "Gaya Hidup Hedonisme Mahasiswa Fakultas Ekonomi Dan Bisnis Universitas Sam Ratulangi Di Kota Manado," Fakultas Ekonomi dan Bisnis Universitas Samratulangi Manado, no. Gaya Hidup Hedonisme Mahasiswa (n.d.): 2.
} 
Masih terkaitan dengan pengertian dari gaya hidup, Kasali juga mengemukakan bahwa gaya hidup pada prinsipnya adalah bagaimana seseorang menghabiskan waktu dan uangnya. ${ }^{15}$ Menurut Yupriel, gaya hidup diartikan sebagai pola tingkah laku seharihari segolongan manusia dalam masyarakat. ${ }^{16}$ Melalui pernyataan Kasali dan Yupriel ini kita dapat mengetahui bahwa ada penegasan-penegasan utama yang perlu kita perhatikan ketika kita memaknai apa itu gaya hidup, yang pertama berbicara mengenai gaya hidup berarti kita bicara tentang perilaku seseorang dalam menghabiskan waktu dan uangnya, Kasali tidak menjelaskan uangnya dihabiskan untuk apa, namun tentunya penulis mengerti bahwa menghabiskan uang berarti ada sesuatu yang dibeli dan mungkin ada sesutu yang digunakan dengan menghabiskan waktu. Hal kedua yang penulis mengerti dari pernyataan kedua tokoh di atas adalah, ketika berbicara tentang gaya hidup maka tidak secara langsung kita sedang berbicara tentang pola dan tingkah laku manusia setiap hari. Yupriel tidak menjelas pola dan tingkah laku itu secara detail namun yang penulis mengerti bahwa pola tingkah laku setiap hari ini adalah segala sesuatu yang manusia lakukan dalam bentuk tindakan setiap hari

Berangkat dari beberapa argumen terkait dengan pengertian gaya hidup di atas maka penulis menarik satu kesimpulan bahwa gaya hidup adalah suatu pola perilaku yang ada pada manusia yang selalu dilakukan dalam aktivitasnya setiap hari, baik untuk memenuhi keinginannya sendiri maupun untuk memenuhi kepentingan banyak orang, yang sedianya dilakukan secara terus menerus dalam hidupnya.

\section{B. Hedonisme}

Zaman ini, manusia selalu menemukan dan menjalani kehidupannya dengan berbagai aliran dan pengajaran, yang mana aliran dan pengajaran ini juga ikut terlibat dalam membentuk dan mengarahkan manusia itu sendiri untuk menemukan hal atau bagian seperti apa yang sesuai dan cocok dengan kehidupannya. Tentu bahwa hal serupa ini juga terjadi ketika kita berbicara mengenai apa itu hedonisme, seperti yang kita ketahui bahwa hedonisme adalah bagian dari aliran filsafat moral yang berkembang hingga saat ini, yang juga memiliki pengaruh dan peran yang sangat signifikan pada gaya Hidup manusia. Hedonisme itu sendiri secara etimologi kata berasal dari Bahasa Yunani yaitu Hedonimos dari akar kata hedone yang berarti "kesenangan". Paham ini berusaha menjelaskan tentang apa yang baik, memuaskan keinginan manusia dan apa yang meningkatkan kualitas kesenangan itu sendiri. ${ }^{17}$.

Masih terkait dengan hedonisme Razali juga mengemukakan bahwa hedonisme merupakan suatu pandangan hidup yang menganggap bahwa orang akan menjadi bahagia dengan mencari kebahagiaan sebanyak mungkin dan sedapat mungkin menghindari perasaan-perasaan yang menyakitkan. ${ }^{18}$ Razali menegaskan bahwa kehidupan hedonisme adalah suatu anggapan yang membuat seseorang untuk selalu mencari kebahagiaan dan berusaha untuk menghindarkan diri dari segala sesuatu yang menyakitkan. Dalam kaitannya dengan kebahagiaan yang menjadi penekanan dalam tulisan ini, Raja Oloan mengemukakan bahwa Epicurus juga mengambil banyak paham

15 Kasali, Membidik Pasar Indonesia: Segmentasi, Targetting, Positioning, 225.

16 Juolanda Tambingon, Femi C.M Tasik, “Gaya Hidup Hedonisme Mahasiswa Fakultas Ekonomi Dan Bisnis Universitas Sam Ratulangi Di Kota Manado,” 2.

17 Sigit Wibawanto, “Gaya Hidup Hedonisme Terhadap Perilaku Pembelian Di Pasar Modern," Fokus Bisnis 15, no. 01 (2016): 62.

18 Ramadhan Razali, "Perilaku Konsumen: Hedonisme Dalam Perspektif Islam,” JESKaPe 04, no. 01 (2020): 117. 
mengenai isu tentang hedonisme dalam mencari kebahagiaan, sebagaimana Epicurus mengajarkan bahwa tugas filsafat adalah menemukan cara untuk meraih kebahagiaan. ${ }^{19}$

Melihat berbagai pandangan dan uraian di atas dalam kaitanya dengan apa itu hedonisme maka, penulis dapat memberi suatu kesimpulan bahwa hedonisme adalah pandangan hidup yang menekankan dan mengajarkan tentang kesenangan dan kebahagiaan adalah sesuatu yang penting untuk dimiliki oleh manusia, atau dengan pengertian yang lain bahwa manusia hidup memerlukan kebahagiaan. Kebahagiaan yang dimengerti dalam pandangan hedonisme adalah bagaimana manusia hidup dengan memuaskan segala keinginannya untuk bahagia.

\section{Gaya Hidup Hedonisme}

Esksistensi manusia pada suatu tempat, tidak dapat dipisahkan dengan suatu gaya hidup yang melekat pada manusia itu sendiri. Sebagaimana yang dikemukakan oleh Minor dalam jurnalnya Hatane Samuel bahwa gaya hidup adalah pola hidup seseorang di dunia yang diekspresikan dalam aktivitas, minat dan opininya. ${ }^{20}$ masih terkait dengan gaya hidup Kotler dan Amstrong dalam jurnalnya Ranti Tri Angreini mengatakan bahwa Gaya hidup merupakan salah satu faktor yang dapat mempengaruhi prilaku konsumtif, sebagaimana yang terlihat dalam pola kehidupannya yang dicerminkan melalui kegiatan, minat dan opini dalam berinteraksi pada lingkungan sekitarnya. ${ }^{21}$ Sedangkan Berkaitan dengan kebahagiaan yang menjadi penekanan utama ketika membahas tentang hedonisme merupakan suatu kenikmatan yang dialami oleh seseorang, baik dalam pikiran, Tindakan dan perasaan, tentu bahwa bahagia atau kebahagiaan juga identik dengan suatu kesenangan yang sedang dialami oleh seseorang. Dengan demikian bahwa bahagia itu berarti senang, nikmat serta adanya suatu kesesuaian antara apa yang kita inginkan terhadap apa yang kita peroleh dan nikmati.

Kebahagiaan yang dialami oleh seseorang tentu tidak dapat dipisahkan juga dengan Gaya hidup yang dimiliki oleh orang tersebut, hal ini terjadi karena kebahagiaan yang dialami tentu akan terlihta juga dalam gaya hidup yang dimiliki oleh orang tersebut. Lalu apa sebetulnya gaya hidup itu? Enggel Blacwell dalam jurnalnya Sari Listyorini mengemukakan bahwa gaya hidup adalah pola dimana orang hidup dan menggunakan uang dan waktunya. ${ }^{22}$ masih berkaitan dengan gaya hidup Kotler juga dalam jurnalnya Fatiah Nur Azizah mengatakan bahwa gaya hidup adalah pola interaksi seseorang yang diungkapkan dalam kegiatan minat dan pendapatnya. ${ }^{23}$ Melihat keterkaitan yang begitu erat antara perilaku manusia yang dapat juga terlihat dalam suatu gaya hidup, maka akan memunculkan suatu dorongan bagi kita untuk bertanya apa sebetulnya gaya hidup hedonisme yang menjadi penekanan penting dalam topik ini?

Gaya hidup hedonisme adalah suatu pola hidup yang mencari kesenangan seperti banyak menghabiskan waktu di luar rumah, lebih banyak bermain, dan senang membeli barang-barang mahal. ${ }^{24}$ Masih terkait dengan gaya hidup hedonisme, Musma Muis juga

19 Raja Oloan Tumanggor, "Pemahaman Well-Being Dari Perspektif Filsafat," Jurnal Muara sosial, Humaniora dan Seni 02, no. 01 (2018): 351.

${ }^{20}$ Hatane Samuel Metha Nilarisma Dwi, "Pengaruh Gaya Hidup (Lifestile) Harga, Promosi Terhadap Pemilihan Tempat Tujuan Wisata (Destination) Studi Kasus Pada Konsumen Artojaya Tour Dan Travel Surabaya," Manajemen Pemasaran Perta 03, no. 01 (2015): 3.

${ }^{21}$ Ranti Tri Anggriani \& Fauzan Heru Santhoso, "Hubungan Antara Gaya Hidup Hedonis Dengan Perilaku Konsumtif Pada Remaja," Gadjah Mada Journal Of Psychology 3, no. Gaya Hidup Hedonis (2017): 133.

22 Sary Listyorini, "Analisis Faktor-Faktor Gaya Hidup Dan Pengaruhnya Terhadap Pembelian Rumah Sehat Sederhana," Administrasi Bisnis Universitas Briwijaya Malang 01, no. 01 (2012): 14.

${ }^{23}$ Fatia Nur Azizah, "Kontrol Diri Dan Gaya Hidup Hedonis Pada Mahasiswa Fakultas Ekonomika Dan Bisnis Universitas Diponegoro," 157.

${ }^{24}$ Sigit Wibawanto, "Gaya Hidup Hedonisme Terhadap Perilaku Pembelian Di Pasar Modern," 62. 
memberikan pandangannya yaitu berkaitan dengan bagaimana seseorang menghabiskan waktu dan uangnya untuk bersenang-senang. Hal serupa ini juga dikemukakan oleh Iin Emy Prastiwi bahwa gaya hidup hedonisme adalah suatu pola hidup yang aktivitasnya hanya mencari kesenangan dan kenikmatan materi, yang juga berkeyakinan akan pentingnya harta dalam hidup dan menjadikan materi sebagai sumber kepuasan dan ketidakpuasan. ${ }^{25}$.

Melihat beberepa pendapat ini penulis mengerti bahwa gaya hidup hedonisme yang dimaksudkan di sini adalah suatu pola hidup yang ada pada manusia dengan berusaha mencari kesenangan, yang terlihat dalam berbagai kegiatan dan aktivitasnya setiap hari yaitu misalnya menghabiskan waktu dan uang untuk segala sesuatu yang mendatangkan kenikmatan bagi dirinya sendiri. Hal ini tentu terjadi karena orang yang memegang aliran hedonisme beranggapan bahwa kenitmatan materi adalah hal yang paling penting dalam hidup ini, sehingga seseorang perlu untuk memuaskan dirinya dengan apa yang dapat diraih dan diperolehnya.

\section{Hedonisme dalam Roma 6:12}

Untuk memahami dan mengemukakan perilaku Hedonisme dalam Ayat ini maka penulis merumuskan beberapa terjemahan yang secara detail membicarakan tentang teks ini. Terjemahan pertama yang penulis gunakan dalam menemukan perilaku hedonisme dalam Roma 6:12 yaitu: "Sebab itu hendaklah dosa jangan berkuasa lagi di dalam tubuhmu yang fana, supaya kamu jangan lagi menuruti keinginannya" kata

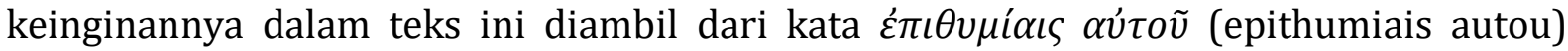
dalam Bahasa Yunani yang berarti: menginginkan dirinya sendiri. Secara gramatikal

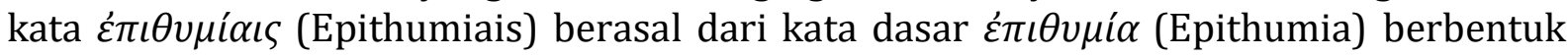
noun dative feminine plural common ${ }^{26}$ : yaitu Keinginanan yang merukuk kepada banyak perempuan, yang melanggar hukum adat dan hukum kasus. Frasa mengikuti keinginannya yang dibicarakan dalam bagian ini memberikan pengertian bahwa adanya suatu perilaku yang hanya mau mengikuti keinginan diri sendiri serta memuaskannya tanpa melihat orang lain apalagi Tuhan. Tentu bahwa orang yang selalu mengikuti keinginannya yang dibicarakan pada bagian ini sesuai dengan perilaku hedonisme yang menjadi penekakan dalam topik ini.

Berkaitan dengan makna atau perilaku hedonisme yang dibicarakan dalam Roma 6;12, di dalam terjemahkan Alkitab masa kini memberikan penjelasan bahwa orang percaya tidak boleh menggunakan anggota tubuhnya sebagai senjata kelaliman, sebab jika demikian maka akan terus menerus membuat dosa, namun sebagai orang percaya harus menyerahkan diri untuk hidup suci. Dengan demikian maka perilaku hedonisme yang ditekankan dalam bagian ini adalah, suatu tindakan atau perilaku dimana seseorang selalu mengikuti keinginananya sendiri dan tidak mengikuti keinginan Tuhan. ${ }^{27}$ selain itu dalam tafsiran Alkitab Wycliffe Volume 3 terkait dengan Roma 6:12 mengatakan bahwa orang yang menuruti keinginannya sendiri adalah orang yang hidup dalam dosa dan kasih Kristus tidak ada padanya. ${ }^{28}$

Dengan demikian maka perilaku hedonisme yang dibicarakan dalam Roma 6:12 adalah, suatu perilaku dimana seseorang yang selalu mengikuti keinginannya dengan

25 Prastiwi, Iin Emi, “Budaya Hedonisme Dan Konsumtif Dalam Belanja Online Ditinjau Dari Perpektif Ekonomi Syariah,” 732.

26 Welly Pandensolang, Gramatika Dan Sintaksis Bahasa Yunani Perjanjian Baru, YAI Press. (Jakarta, 2010), 12-14.

27 Yayasan Komunikasi Bina Kasih, Tafsiran Alkitab Masa Kini 3, Inter-Vers. (London, 2013), 432.

${ }^{28}$ Charles F. Pfeiffer dan Everett F. Harrison, Tafsiran Alkitab WYCLIFFE, Gandum Mas. (Malang, 2008), 547. 
mengabaikan keinginan Tuhan. sebagaimana keinginannya yang dimaksudkan di sini adalah, suatu perbuatan atau perilaku yang lebih mengutamakan kesenangan diri sendiri dari pada menyenangkan hati Tuhan.

\section{E. Hedonisme dalam Galatia 5:19}

Masih terkait dengan teks Alkitab dalam Perjanjian Baru yang berbicara tentang perilaku hedonisme sebagaimana yang telah penulis uraikan pada bagian sebelumnya, pada bagian ini penulis akan menganalisa teks Galatia 5:19 dengan cara melihat beberapa terjemahan untuk memperlihatkan makna dari perilaku hedonisme dalam Surat Paulus kepada jemaat di Galatia yaitu: "Perbuatan daging telah nyata, yaitu: percabulan, kecemaran, hawa nafsu". Dalam ayat ini dapat ditemukan frasa yang menunjuk pada perilaku hedonisme. yaitu "perbuatan daging". Frasa ini berasal dari Bahasa Yunani yaitu: ع̋ $\rho \gamma \alpha \tau \tilde{\eta} \varsigma \sigma \alpha \rho \kappa o ́ \varsigma$ (erga tes sarkos) yang berarti "bekerja dari daging”. Secara gramatikal kata $\sigma \alpha \rho \kappa o ́ \varsigma$ (Sarkos) dari kata dasar $\sigma \alpha ́ \alpha \xi$ (sarks) berbentuk noun genitive feminine singular yaitu: adanya keinginan dalam diri sendiri untuk menikmati sesuatu (wanita atau perempuan muda). Melihat terjemahan Bahasa Yunani di atas ini maka, perbuatan atau perilaku hedonisme yang dibicarakan dalam ayat ini adalah adanya suatu perbuatan yang terus dilakukan oleh manusia yang didorong oleh keinginan daging, yang hanya bertujuan untuk memuaskan keinginan diri sendiri.

Masih berkaitan dengan teks Galatia 5:19 Tafsiran Alkitab wycliffe memberikan penjelasan bahwa perbuatan daging dapat diduga berkembang dengan bebas di dalam lingkungan legalisme. Hawa nafsu yang dibicarakan dalam ayat ini berbicara juga tentang perilaku gaya hidup yang mau ingin untuk bersenang-senang. ${ }^{29}$, dengan melihat urain dalam tersiran ini maka tentu teks Galatia 5:19 secara jelas berbicara tentang suatu perilaku yang merujuk pada kehidupan pola hidup hedonisme yang mungkin sedang atau telah terjadi pada kehidupan orang-orang percaya yang ada di Galatia, sehingga Paulus harus memberikan suatu peringatan kepada mereka supaya tidak terjerumus di dalamnya.

Selain terjemahan yang telah penulis uraikan di atas, Alkitab tafsiran masa kini juga memberikan suatu penjelasan yang berbeda yaitu dalam Galatia 5:19 selain berbicara tentang dosa seksual, praktik kekafiran, dosa perasaan dan kedurhakaan. Dalam bagian ini juga berbicara tentang adanya suatu keinginan untuk selalu mementingkan diri sendiri, dan tidak mengutamakan orang lain. ${ }^{30}$, tentu bahwa mementingkan diri sendiri yang dimaksudkan di sini adalah, adanya suatu tindakan yang selalu ingin mencari segala sesuatu untuk menemukan kebahagiaan sendiri tanpa memperhatikan kehidupan orang lain.

Dengan demikian maka perilaku hedonisme yang dibicarakan dalam Galatia 5:19 adalah, suatu gaya hidup yang hanya mengikuti keinginan daging atau keinginan diri sendiri, yaitu adanya suatu perilaku yang hanya mementingkan diri sendiri tanpa melihat kehidupan sesama manusia yang terlihat dalam kehidupan sehari-hari yaitu kemabukan, pesta posa, keinginan untuk memiliki harta orang lain, dan semua perbuatan yang tidak sesuai dengan keinginan Tuhan namun hanya mengikuti keinginan diri sendiri.

\section{Hasil Temuan}

Pada bagian ini terdapat tiga poin penting yang penulis ambil berdasarkan kehidupan hedonisme yang telah penulis uraikan di atas. sehingga bagian ini menjadi implikasi secara khusus kepada orang percaya masa kini, agar orang Percaya dapat

\footnotetext{
${ }^{29}$ Ibid., 729.

30 Yayasan Komunikasi Bina Kasih, Tafsiran Alkitab Masa Kini 3, 571.
} 
hidup sesuai dengan kehendak Tuhan bukan kehendak yang sesuai dengan gaya hidup Hedonisme.

\section{Orang Kristen Hidup menurut Keinginan Tuhan.}

Allah rindu agar semua orang percaya, memiliki perubahan dalam hidup dan wawasan serta semangat yang baru berdasarkan visi Allah, tentu bahwa Allah juga ingin agar orang percaya mau melakukan kehendak-Nya dengan taat, dan berjalan sesuai dengan maksud-Nya, serta mampu berdiri teguh dalam mengantisipasi tantangan zaman ini, yang mana manusia dituntut untuk mengutakaman kehidupan yang secara vertikal yaitu kehidupan yang sesuai dengan Keinginana Allah. ${ }^{31}$ Dalam zaman modern ini banyak orang yang merasa seakan-akan tidak mampu mengaktualisasikan dirinya di tengah arus dan perubahan zaman yang terjadi begitu cepat, luas dan tak dapat diramalkan sebelumnya. Dengan demikian maka untuk merealisasikan harapan Allah terhadap generasi kita saat ini kita perlu sungguh-sungguh memahami bahwa orang percaya harus menjadi garam dan terang dunia. ${ }^{32}$

Bertolak dari topik dan uraian yang telah dibahas pada pokok-pokok sebelumnya berkaitan dengan perilaku hedonisme, maka kita dapat berkesimpulan bahwa orang yang terjerumus dalam perilaku hedonisme adalah orang yang selalu mau mengikuti keinginannya sendiri. Namun sebagai orang percaya tentu hal ini bertentangan dengan pengajar dalam kekristenan yaitu orang percaya dituntut untuk hidup menurut keinginan Tuhan, berkaitan dengan hal ini, maka perlu untuk kita mengerti satu pertanyaan penting pada bagian ini yang yaitu apa dimaksud dengan hidup menurut keinginan Tuhan?

Dalam keseluruhan isi dari Alkitab Tuhan mengiginkan 2 hal utama yang perlu dilakukan oleh umatnya yaitu hidup mengasihi Tuhan dengan segenap hati dan mengasihi sesama seperti mengasihi diri sendiri. Bagian dimana kita berbicara tentang hidup menurut keinginan Tuhan adalah suatu usaha dalam diri orang percaya untuk hidup mengasihi Tuhan, dalam usaha untuk hidup menurut keinginan Tuhan ini, ada hal-hal yang perlu dilakukan oleh orang percaya yang menjadi tanda bahwa hidup dan perilakunya telah sesuai dengan keinginan Tuhan bukan keinginan sendiri. Pertama, orang percaya perlu hidup dalam kekudusan. Ben Elliot mengatakan bahwa kekudusan adalah kasih kemenangan Kristus atas dosa di dalam kita. ${ }^{33}$ Supaya kita sungguhsungguh memahami pengudusan ini, Ben juga menambahkan, bahwa kita perlu menghimpun tiga hal penting yaitu pengudusan adalah sesuatu yang dikerjakan oleh Kristus, pengudusan adalah sesuatu yang diwujudkan oleh Roh Kudus dan pengudusan adalah sesuatu yang terlihat dalam cara kita menjalani kehidupan sehari-hari. Ketika seorang percaya memahami tiga hal ini berkaitan dengan Kekudusan maka, akan medorong dan menyadarkan dirinya untuk mau hidup selalu dekat dengan Tuhan dan meninggalkan segala sesuatu yang hanya mendatangkan keinginan sendiri atau keinginan daging, sebagaimana hidup dalam kekudusan adalah hidup yang menang atas daging dan menolah perbuatan dosa.

Kedua, sebagai orang percaya hidup menurut keinginan Tuhan adalah bekerja bagi Allah. Sebagaimana yang kita ketahui dalam pengajaran Akitab, khususnya dalam Matius 28:19-20, orang percaya dituntut untuk meneruskan misi Tuhan yang menjadi amanat Agung Tuhan Yesus, yang pada intinya mengajarkan kita untuk bekerja Bagi Allah. Namun yang menjadi pertanyaannya adalah apa yang kita kerjakan bagi Allah? Kembali kepada isi dari Matius 28:19-20 bahwa Tuhan mengendaki kita menyerahkan diri kita

31 Bob Hostetler, Hidup Kudus (Bandung: Yayasan Kalam Hidup, 2002), 45-48.

${ }^{32}$ Suhandhy Susantio, Sendirian Dengan Allah (Bandung: Yayasan Kalam Hidup, 2004), 17.

${ }^{33}$ Ben Elliott, Tetap Teguh (Bandung: Kalam Hidup, 2015), 86-87. 
bagi pekerjaannya, sesuai dengan bagian yang mampu kita kerjakan sesuai dengan rencana Tuhan dalam hidup kita. Jika bagian kita adalah mengajar tentang kebenaran maka kita harus melakukannya. Jika bagian kita adalah memberitakan injil, maka hendaklah kita melakukannya. Jika bagianya kita adalah bekerja memberi buah bagi sesama kita maka lakukanlah sesuai dengan kesungguhan hati kita. Hickey mengatakan bahwa kita harus memiliki iman yang kuat kepada Allah sehingga kita mampu mengerjakan pekerjaan yang mendatangkan kemuliaan bagi nama-Nya ${ }^{34}$

\section{Menjauhkan Diri terhadap Perbuatan yang Bersumber dari Keinginan Daging.}

Keinginan yang timbul dalam diri manusia selalu didasar pada dua hal yaitu keinginan daging dan keinginan Roh, kemudian akan menghasilkan perbuatan seperti apa yang hendak dilakukan, dalam memahami 2 dasar ini, keinginan daging selalu menjurus kepada keinginan diri sendiri dan keinginan Roh adalah keinginan yang berdasarkan pada kehendak Tuhan. Dalam memahami perbuatan dan perilaku hedonisme dalam pokok perbahasan yang telah penulis uraikan sebelumnya, perilaku hedonisme adalah perilaku yang selalu berdasarkan pada keinginan daging atau keinginan diri sendiri.

Dalam menjalani kehidupan sesuai dengan konteks pengajaran kekristenan orang percaya dituntut untuk hidup sesuai dengan keinginan Roh bukan keinginan daging, seperti yang dilakukan oleh orang-orang yang berada dalam katergori hedonisme. Dengan demikian maka sebagai orang Kristen yang hidup dalam kehidupan rohani perlu untuk menjauhkan diri dari perbuatan daging sehingga tidak terjerumus dalam perilaku atau perbuatan hedonisme. Namun yang menjadi pertanyaan adalah apa yang kita harus lakukan sehingga terhindar dari perbuatan yang bersumber dari keinginan daging? Pertama, tekun dalam doa, salah satu pekerjaan utama dan terutama dalam kehidupan orang percaya adalah berdoa, dengan berdoa maka kita akan mendapatkan kekuatan dari Tuhan untuk mengalahkan segala keinginan dosa, sebagaimana dapat kita mengerti dalam pengajaran Firman Tuhan. Orang percaya dituntut untuk bertekun di dalam doa, sehingga dapat menang atas dosa atau keinginan daging. Kedua, membaca dan merenungkan Firman dalam kehidupan setiap hari. Dalam Mazmur 119:105, Daud menuliskan bahwa Firman Tuhan Pelita bagi kaki-Ku dan terang bagi jalan-Ku, dengan menjadikan Firman Tuhan menjadi pelita dan terang bagi jalan hidup maka akan menjadi orang percaya yang mampu hidup dalam keinginan Roh dan mengalahkan keinginan daging dalam diri Kita.

\section{Memaknai Kebahagiaan yang Abadi.}

Menjadi pribadi yang selalu hidup bahagia adalah sesuatu yang sangat dirindukan oleh setiap orang, sebab dengan bahagia seseorang dapat hidup dengan tenang dalam menjalani hidupnya. Namun menjadi penting juga ketika kita memahami kebahagiaan adalah apa yang medorong dan menjadi sumber dari semua kebahagiaan yang kita rindukan dalam hidup itu sendiri. Dalam pemahaman hedonisme, menekankan bahwa manusia perlu mengejar dan bekerja untuk menghasilkan kebahagiaan untuk diri sendiri, yang mana kebahagiaan di dunia ini adalah sesuatu yang perlu dikejar dan diraih oleh seseorang. Berkaitan dengan hal ini, orang Kristen diajarkan untuk hidup dalam salib Kristus, yaitu menderi dalam melayani seperti Yesus Kristus. Yang menjadi pertayaan adalah apakah dalam pengajaran kekristenan tidak ada kebahagiaan? Tentu jawabannya adalah ada, namun kebahagiaan yang diajarkan dan dimengerti dalam perspektif Iman Kristen jauh berbeda dengan apa yang diajarkan dalam prinsip hedonisme, yang mana kebahagiaan dalam konteks kekristenan adalah kebahagiaan

${ }^{34}$ Marilyn Hickey, Iman Yang Membuat Doa Terjawab (Yogyakarta: ANDI, 2007), 35-37. 
yang tidak dinikmati di bumi ini, namun kebahagiaan yang akan didapatkan di Surga Bersama dengan Yesus.

Dengan demikian maka, sebagai orang Kristen, perlu untuk memahami konteks kebahagiaan tidak hanya dalam konteks hedonisme namun melampaui konsep hedonisme yaitu kebahagiaan yang kekal di Surga. Sebagaimana yang dikemukakan oleh B. D. Bartruff bahwa, orang percaya harus senantiasa berbahagia dan bersukacita dalam Tuhan, ${ }^{35}$ yang memiliki pengertian lain yaitu, dalam keadaan apa pun orang Kristen harus selalu bahagia, dengan tidak didasarkan pada keinginan daging atau keinginan diri sendiri, namun berdasarkan pada keinginan Tuhan.

\section{Kesimpulan}

Mencari kebahagiaan dalam hidup ini adalah sesuatu yang selalu didambakan oleh semua orang yang hidup di Planet bumi ini, nanum dalam mencari dan menemukan kebahagiaan ini, seseorang perlu untuk dibimbing dan didorong oleh suatu motivasi yang benar agar, kebahagiaan yang dia peroleh dapat dinikmati dengan baik, bukan untuk memuaskan keinginannya, sebagaimana yang diajarkan dalam Alkitab bahwa manusia harus selalu hidup mencari dan menyenangkan hati Tuhan. melihat persoalan kebahagiaan ini yang menjadi penekanan utama dalam memahami konsep gaya hidup hedonisme ini, maka dalam tulisan ini penulis dapat menyimpulkan beberapa hal yaitu:

Pertama, gaya hidup adalah suatu pola perilaku yang ada pada manusia yang selalu dilakukan dalam aktivitasnya setiap hari, baik untuk memenuhi keinginannya sendiri maupun untuk memenuhi kepentingan banyak orang, yang sedianya dilakukan secara terus menerus dalam hidupnya. Kedua, gaya hidup hedonisme adalah suatu pola hidup yang ada pada manusia dengan berusaha mencari kesenangan, yang terlihat dalam berbagai kegiatannya setiap hari yaitu menghasbiskan waktu dan uang untuk segala sesuatu yang mendatangkan kenikmatan bagi dirinya sendiri. Ketiga, hedonisme dalam Roma 6:12 dan Galatia 5:19 adalah suatu gaya hidup yang hanya mengikuti keinginan daging atau keinginan diri sendiri, yaitu adanya suatu perilaku yang hanya mementingkan diri sendiri tanpa melihat kehidupan sesama manusia yang lain. Keempat, implikasi bagi orang percaya adalah: pertama, orang percaya harus selalu hidup menurut keinginan Tuhan, yaitu melakukan hal-hal yang memperlihatkan kasih kepada Allah. Kedua, orang percaya sebaikanya menjauhkan diri dari perbuatan yang bersumber dari keinginan daging. Ketiga, orang percaya sebaiknya selalu mengejar kebahagiaan yang abadi bukan kebahagiaan sementara yang diajarkan dalam paham hedonisme.

\section{Referensi}

B.D. Bartruff. Menjadi Pribadi Yang Di Kedendaki Tuhan. Jakarta: Gunung Mulia, 2005.

Bob Hostetler. Hidup Kudus. Bandung: Yayasan Kalam Hidup, 2002.

Ch. Suryanti. "Agama Dan Iptek: Refleksi Dan Tantangannya Dalam Mengembangakan Moralitas Anak Muda.” Orientasi Baru 19, no. Agama dan IPTEK (2010): 155-170.

Creswell, John W. Research Design, Pendekatan Metode Kualitatif, Kuantitatif, Dan Campuran. 4th ed. Yogyakarta: Pustaka Pelajar, 2016.

Ben Elliott. Tetap Teguh. Bandung: Kalam Hidup, 2015.

Fatia Nur Azizah, Endang Sri Indrawati. "Kontrol Diri Dan Gaya Hidup Hedonis Pada

35 B.D. Bartruff, Menjadi Pribadi Yang Di Kedendaki Tuhan (Jakarta: Gunung Mulia, 2005), 102-103. 
Mahasiswa Fakultas Ekonomika Dan Bisnis Universitas Diponegoro." Jurnal Empati Volume 4 (n.d.): 156-162.

Gertz, Jan Christian, Angelika Berlejung, and Konrad Schmid Markus Witte. Purwa Pustaka, Eksplorasi Ke Dalam Kitab-Kitab Perjanjian Lama Dan Deuterokanonika. 1st ed. Jakarta: BPK Gunung Mulia, n.d.

Harrison, Charles F. Pfeiffer dan Everett F. Tafsiran Alkitab WYCLIFFE. Gandum Mas. Malang, 208AD.

Haryono Makoagow dan Lamsike Pateda. "Pengaruh Gaya HIdup Hedonisme Dan Dampaknya Terhadap Hasil Belajar PAI DI SMAN 1 Pinolosian Kab. Bolaang Monggondow Selatan." Jurnal Pendidikan Agama Islam dan Budi Pekerti 1, no. 2 (2019).

Hendrik Rawambaku. Metode Penelitian Pendidikan. Jakarta: BPK Gunung Mulia, 2015.

Juolanda Tambingon, Femi C.M Tasik, Antonius Purwanto. “Gaya Hidup Hedonisme Mahasiswa Fakultas Ekonomi Dan Bisnis Universitas Sam Ratulangi Di Kota Manado." Fakultas Ekonomi dan Bisnis Universitas Samratulangi Manado, no. Gaya Hidup Hedonisme Mahasiswa (n.d.): 1-8.

Karl Bertens. ETIKA. Jakarta: Gramedia Pustaka Utama, 2004.

Kasali, R. Membidik Pasar Indonesia: Segmentasi, Targetting, Positioning. Jakarta: Gramedia Pustaka Utama, 2008.

Marilyn Hickey. Iman Yang Membuat Doa Terjawab. Yogyakarta: ANDI, 2007.

Metha Nilarisma Dwi, Hatane Samuel. "Pengaruh Gaya Hidup (Lifestile) Harga, Promosi Terhadap Pemilihan Tempat Tujuan Wisata (Destination) Studi Kasus Pada Konsumen Artojaya Tour Dan Travel Surabaya." Manajemen Pemasaran Perta 03, no. 01 (2015): 1-13.

Pandensolang, Welly. Gramatika Dan Sintaksis Bahasa Yunani Perjanjian Baru. YAI Press. Jakarta, 2010.

Peter Garlans. Jangan Menjadi Budak Uang. Jakarta: Penerbit Guepedia, 2009.

Prastiwi, Iin Emi, Tira Nur Fitria. "Budaya Hedonisme Dan Konsumtif Dalam Belanja Online Ditinjau Dari Perpektif Ekonomi Syariah." Jurnal Ilmiah Ekonomi Islam 04, no. 2 (2020): 731-736.

Raja Oloan Tumanggor. "Pemahaman Well-Being Dari Perspektif Filsafat." Jurnal Muara sosial, Humaniora dan Seni 02, no. 01 (2018): 350-358.

Ramadhan Razali. "Perilaku Konsumen: Hedonisme Dalam Perspektif Islam." JESKaPe 04, no. 01 (2020): 115-124.

Ranti Tri Anggriani \& Fauzan Heru Santhoso. "Hubungan Antara Gaya Hidup Hedonis Dengan Perilaku Konsumtif Pada Remaja." Gadjah Mada Journal Of Psychology 3, no. Gaya Hidup Hedonis (2017): 131-140.

Sary Listyorini. "Analisis Faktor-Faktor Gaya Hidup Dan Pengaruhnya Terhadap Pembelian Rumah Sehat Sederhana." Administrasi Bisnis Universitas Briwijaya Malang 01, no. 01 (2012): 12-24.

Sigit Wibawanto. "Gaya Hidup Hedonisme Terhadap Perilaku Pembelian Di Pasar Modern." Fokus Bisnis 15, no. 01 (2016): 54-71.

Suhandhy Susantio. Sendirian Dengan Allah. Bandung: Yayasan Kalam Hidup, 2004.

Trimiarti, Novita. "Studi Kasus Tentang Gaya Hidup Hedonisme Mahasiswa Bimbingan Dan Konseling Universitas Ahmad Dahlan.” Psikopedagogian Vol.3 (2014): 20-28.

Yayasan Komunikasi Bina Kasih. Tafsiran Alkitab Masa Kini 3. Inter-Vers. London, 2013. 